Check for updates

Cite this: Metallomics, 2018, 10, 287

Received 30th September 2017 Accepted 30th November 2017

DOI: $10.1039 / \mathrm{c} 7 \mathrm{mt} 00279 \mathrm{c}$

rsc.li/metallomics

\section{The P-type ATPase inhibiting potential of polyoxotungstates $\uparrow$}

\author{
Nadiia Gumerova, (D) a Lukáš Krivosudský, (D) ‡a Gil Fraqueza, (D) bc \\ Joscha Breibeck, (iD a Emir Al-Sayed, (iD a Elias Tanuhadi, (D) a Aleksandar Bijelic, (iD) a \\ Juan Fuentes, (D) ${ }^{b}$ Manuel Aureliano (D) *bd and Annette Rompel (D) *a
}

\begin{abstract}
Polyoxometalates (POMs) are transition metal complexes that exhibit a broad diversity of structures and properties rendering them promising for biological purposes. POMs are able to inhibit a series of biologically important enzymes, including phosphatases, and thus are able to affect many biochemical processes. In the present study, we analyzed and compared the inhibitory effects of nine different polyoxotungstates (POTs) on two P-type ATPases, $\mathrm{Ca}^{2+}$-ATPase from skeletal muscle and $\mathrm{Na}^{+} / \mathrm{K}^{+}$-ATPase from basal membrane of skin epithelia. For $\mathrm{Ca}^{2+}$-ATPase inhibition, an in vitro study was performed and the strongest inhibitors were determined to be the large heteropolytungstate $\mathrm{K}_{9}\left(\mathrm{C}_{2} \mathrm{H}_{8} \mathrm{~N}\right)_{5}\left[\mathrm{H}_{10} \mathrm{Se}_{2} \mathrm{~W}_{29} \mathrm{O}_{103}\right]$ $\left(\mathrm{Se}_{2} \mathrm{~W}_{29}\right)$ and the Dawson-type POT $\mathrm{K}_{6}\left[\alpha-\mathrm{P}_{2} \mathrm{~W}_{18} \mathrm{O}_{62}\right]\left(\mathrm{P}_{2} \mathrm{~W}_{18}\right)$ exhibiting $\mathrm{IC}_{50}$ values of 0.3 and $0.6 \mu \mathrm{M}$, respectively. Promising results were also shown for the Keggin-based POTs $\mathrm{K}_{6} \mathrm{H}_{2}\left[\mathrm{CoW}_{11} \mathrm{TiO}_{40}\right]\left(\mathrm{CoW}_{11} \mathrm{Ti}\right.$, $\left.I C_{50}=4 \mu \mathrm{M}\right)$ and $\mathrm{Na}_{10}\left[\alpha-\mathrm{SiW}_{9} \mathrm{O}_{34}\right]\left(\mathrm{SiW}_{9}, \mathrm{IC}_{50}=16 \mu \mathrm{M}\right), \mathrm{K}_{14}\left[\mathrm{As}_{2} \mathrm{~W}_{19} \mathrm{O}_{67}\left(\mathrm{H}_{2} \mathrm{O}\right)\right]\left(\mathrm{As}_{2} \mathrm{~W}_{19}, \mathrm{IC}_{50}=28 \mu \mathrm{M}\right)$ and the lacunary Dawson $\mathrm{K}_{12}\left[\alpha-\mathrm{H}_{2} \mathrm{P}_{2} \mathrm{~W}_{12} \mathrm{O}_{48}\right]\left(\mathrm{P}_{2} \mathrm{~W}_{12}, \mathrm{IC}_{50}=11 \mu \mathrm{M}\right)$, whereas low inhibitory potencies were observed for the isopolytungstate $\mathrm{Na}_{12}\left[\mathrm{H}_{4} \mathrm{~W}_{22} \mathrm{O}_{74}\right] \quad\left(\mathrm{W}_{22}, \quad \mathrm{IC}_{50}=68 \mu \mathrm{M}\right)$ and the Anderson-type $\mathrm{Na}_{6}\left[\mathrm{TeW}_{6} \mathrm{O}_{24}\right]\left(\mathrm{TeW}_{6}, \mathrm{IC}_{50}=200 \mu \mathrm{M}\right)$. Regarding the inhibition of $\mathrm{Na}^{+} / \mathrm{K}^{+}$-ATPase activity, for the first time an ex vivo study was conducted using the opercular epithelium of killifish in order to investigate the effects of POTs on the epithelial chloride secretion. Interestingly, $1 \mu \mathrm{M}$ of the most potent $\mathrm{Ca}^{2+}$-ATPase inhibitor, $\mathrm{Se}_{2} \mathrm{~W}_{29}$, showed only a minor inhibitory effect (14\% inhibition) on $\mathrm{Na}^{+} / \mathrm{K}^{+}$-ATPase activity, whereas almost total inhibition (99\% inhibition) was achieved using $\mathrm{P}_{2} \mathrm{~W}_{18}$. The remaining POTs exhibited similar inhibition rates on both ATPases. These results reveal the high potential of some POTs to act as P-type ATPase inhibitors, with $\mathrm{Se}_{2} \mathrm{~W}_{29}$ showing high selectivity towards $\mathrm{Ca}^{2+}$-ATPase.
\end{abstract}

Significance to metallomics

We studied the inhibitory effects of nine different polyoxotungstates (POTs) on P-type ATPases in vitro $\left(\mathrm{Ca}^{+}-\mathrm{ATPase}\right)$ and ex vivo ( $\left.\mathrm{Na}^{+} / \mathrm{K}^{+}-\mathrm{ATPase}\right)$. The study reveals that some POTs like the Dawson anion $\left[\mathrm{P}_{2} \mathrm{~W}_{18} \mathrm{O}_{62}\right]^{6-}$, which was highly active in vitro and ex vivo, are potent ATPase inhibitors. Furthermore, there is a charge density-activity correlation for the most potent POTs $\left(\mathrm{IC}_{50}<16 \mu \mathrm{M}\right)$, namely $\mathrm{Se}_{2} \mathrm{~W}_{29}, \mathrm{P}_{2} \mathrm{~W}_{18}, \mathrm{CoW}_{11} \mathrm{Ti}, \mathrm{SiW}_{9}$ and $\mathrm{P}_{2} \mathrm{~W}_{12}$. As P-type ATPases represent pharmacologically important targets due to their important role in health and disease, the here reported bioactive POTs should be considered as possible future metallodrugs.

\footnotetext{
${ }^{a}$ Universität Wien, Fakultät für Chemie, Institut für Biophysikalische Chemie, Althanstraße.14, 1090 Wien, Austria.E-mail: annette.rompel@univie.ac.at; Web: www.bpc.univie.ac.at

${ }^{b}$ Centre of Marine Sciences, University of Algarve, 8005-139 Faro, Portugal

${ }^{c}$ Institute of Engineering, University of Algarve, 8005-139 Faro, Portugal

${ }^{d}$ Faculty of Sciences and Technology, University of Algarve, 8005-139 Faro, Portugal.E-mail: maalves@ualg.pt

$\dagger$ Electronic supplementary information (ESI) available: Positive control experiment for $\mathrm{Na}^{+} / \mathrm{K}^{+}$-ATPase inhibition of ouabain. See DOI: $10.1039 / \mathrm{c} 7 \mathrm{mt} 00279 \mathrm{c}$ \$ On leave from: Comenius University, Faculty of Natural Sciences, Department of Inorganic Chemistry, Mlynská dolina, Ilkovičova 6, 84215 Bratislava, Slovakia.
}

\section{Introduction}

Polyoxometalates (POMs) are metal clusters ${ }^{1}$ that exhibit a broad diversity of structures and outstanding properties leading to their application in various fields such as catalysis, ${ }^{2,3}$ photochemistry ${ }^{4}$ material science, ${ }^{5,6}$ macromolecular crystallography ${ }^{7-15}$ and medicine. ${ }^{16-22}$ POMs can be divided into isopolyanions (IPAs), which consist only of one type of metal atom ( $\mathrm{M}=$ addenda atom), $\left[\mathrm{M}_{m} \mathrm{O}_{y}\right]^{q-}$, and heteropolyanions (HPAs), which contain one or more additional elements ( $\mathrm{X}=$ heteroatom), $\left[\mathrm{X}_{r} \mathrm{M}_{m} \mathrm{O}_{y}\right]^{q-}$. The most common representative of IPAs is the Lindqvist structure, 

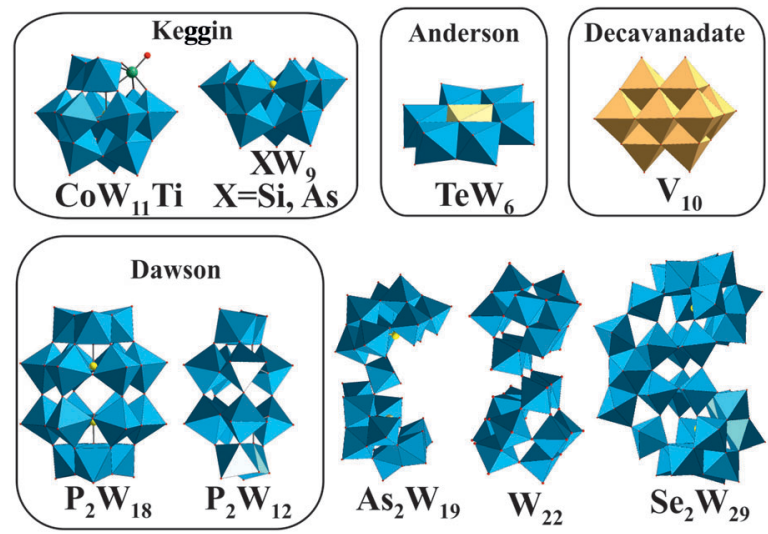

Fig. 1 Structures of the investigated POTs (Table 1 ) and $\left[\mathrm{V}_{10} \mathrm{O}_{28}\right]^{6-}$. Color code: $\mathrm{WO}_{6}$, blue polyhedra; $\mathrm{VO}_{6}$, dark yellow polyhedra; heteroatom, light yellow sphere or polyhedra; $\mathrm{Ti}$ as substituted atom, green sphere.

whereas the well-known Dawson, Keggin and Anderson archetypes belong to the HPAs (Fig. 1). POM research represents an emerging field and especially bioactive POMs are getting more and more attractive due to their ability to interact with important enzymes like alkaline phosphatases, ecto-nucleotidases and ATPases and their potential to interfere with specific cellular processes, such as mitochondria respiration. ${ }^{21-24}$ POMs like decavanadate or Keggin-type polyoxotungstates (POTs) and polyoxomolybdates are currently the focus of biological and biomedical research as they show promising antibacterial and antidiabetic activities, ${ }^{21,22,24-28}$ whereas only few biological studies exist for other POM archetypes such as the Anderson structure. ${ }^{29}$

The main role of the sarcoplasmic reticulum (SR) $\mathrm{Ca}^{2+}$-ATPase is translocation of cellular $\mathrm{Ca}^{2+}$ from the cytoplasm to the SR, which is involved in muscle relaxation. ${ }^{30,31}$ However, $\mathrm{Ca}^{2+}$-ATPase is globally associated with cellular calcium homeostasis, a process of ion transport that is coupled with ATP hydrolysis. ATP hydrolysis follows a well-known mechanism traversing at least four intermediate steps and two protein conformations, namely E1 and E2, with E1 being the conformation with high affinity for the exported substrate and E2 the form with high affinity for the imported substrate. ${ }^{30,31}$ As SR vesicles from skeletal muscle contain a large amount of $\mathrm{Ca}^{2+}$-ATPase, they represent a useful in vitro model to study the effects of drugs and POMs on calcium homeostasis. $^{32,33}$ To our knowledge, only a few POMs, such as decavanadate $\left(\mathrm{V}_{10}\right)$ and decaniobate $\left(\mathrm{Nb}_{10}\right)$, were described to be potent non-competitive inhibitors ( $\mathrm{IC}_{50}=15$ and $35 \mu \mathrm{M}$, respectively) of the hydrolytic activity of SR $\mathrm{Ca}^{2+}$-ATPase. ${ }^{33} \mathrm{Na}^{+} / \mathrm{K}^{+}$-ATPase transports $\mathrm{Na}^{+}$out of the cell while pumping $\mathrm{K}^{+}$into cells and is thus responsible for the ionic and osmotic balance in cells and an important transducer of signals. As all P-type ATPases, the $\mathrm{Na}^{+} / \mathrm{K}^{+}$pump derives energy from ATP hydrolysis.

Herein, we report and compare the effects of nine different POTs (Fig. 1 and Table 1) on the in vitro activity of $\mathrm{Ca}^{2+}$-ATPase from SR. For the first time, we investigate the effects of POTs on the process of epithelial chloride secretion, energized by the activity of basolateral $\mathrm{Na}^{+} / \mathrm{K}^{+}$-ATPase, using an ex vivo model obtained from basal membrane of epithelial skin (killifish). Putative correlations between the inhibitory activity of POTs ( $\mathrm{IC}_{50}$ values), their charge density and size were derived. The results reveal that some POTs are potent inhibitors of P-type ATPases even under almost physiological conditions (ex vivo study) and therefore should be taken into consideration as P-type ATPase targeting drugs. One POT, namely $\mathrm{K}_{9}\left(\mathrm{C}_{2} \mathrm{H}_{8} \mathrm{~N}\right)_{5}\left[\mathrm{H}_{10} \mathrm{Se}_{2} \mathrm{~W}_{29} \mathrm{O}_{103}\right]$ $\left(\mathrm{Se}_{2} \mathrm{~W}_{29}\right)$ showed clear selectivity towards one pump $\left(\mathrm{Ca}^{2+}-\right.$ ATPase), whereas other POTs like the Anderson archetype $\mathrm{Na}_{6}\left[\mathrm{TeW}_{6} \mathrm{O}_{24}\right]$ showed very low inhibition on both ion pumps.

\section{Experimental section}

\section{Polyoxometalates}

The POTs used in this study, $\mathrm{K}_{6}\left[\alpha-\mathrm{P}_{2} \mathrm{~W}_{18} \mathrm{O}_{62}\right] \cdot 14 \mathrm{H}_{2} \mathrm{O},{ }^{35} \mathrm{Na}_{6}-$ $\left[\mathrm{TeW}_{6} \mathrm{O}_{24}\right] \cdot 22 \mathrm{H}_{2} \mathrm{O},{ }^{36} \mathrm{~K}_{6} \mathrm{H}_{2}\left[\mathrm{TiW}_{11} \mathrm{CoO}_{40}\right] \cdot 13 \mathrm{H}_{2} \mathrm{O},{ }^{37} \mathrm{Na}_{10}\left[\alpha-\mathrm{SiW}_{9} \mathrm{O}_{34}\right]$. $16 \mathrm{H}_{2} \mathrm{O},{ }^{35} \mathrm{Na}_{9}\left[\alpha-\mathrm{AsW}_{9} \mathrm{O}_{33}\right] \cdot 27 \mathrm{H}_{2} \mathrm{O},{ }^{38} \mathrm{~K}_{12}\left[\alpha-\mathrm{H}_{2} \mathrm{P}_{2} \mathrm{~W}_{12} \mathrm{O}_{48}\right] \cdot 16 \mathrm{H}_{2} \mathrm{O},{ }^{35}$ $\mathrm{K}_{14}\left[\mathrm{As}_{2} \mathrm{~W}_{19} \mathrm{O}_{67}\left(\mathrm{H}_{2} \mathrm{O}\right)\right] \cdot 23 \mathrm{H}_{2} \mathrm{O},{ }^{39} \mathrm{~K}_{9}\left(\mathrm{C}_{2} \mathrm{H}_{8} \mathrm{~N}\right)_{5}\left[\mathrm{H}_{10} \mathrm{Se}_{2} \mathrm{~W}_{29} \mathrm{O}_{103}\right] \cdot 30 \mathrm{H}_{2} \mathrm{O}^{40}$ and $\mathrm{Na}_{12}\left[\mathrm{H}_{4} \mathrm{~W}_{22} \mathrm{O}_{74}\right] \cdot 50 \mathrm{H}_{2} \mathrm{O}^{41}$ (Table 1 and Fig. 1), were synthesized according to published procedures (see references in Table 1) and their identity was confirmed by infrared spectroscopy. Stock solutions of POTs were freshly prepared by dissolving the solid compound in water and keeping the solution on ice to avoid POT decomposition. The concentrations of the stock solutions were $10 \mathrm{mM}$ and $1 \mathrm{mM}$ for all POTs except for $\mathrm{Se}_{2} \mathrm{~W}_{29}$ (1 $\mathrm{mM}$ and $\left.0.1 \mathrm{mM}\right)$.

\section{Preparation of sarcoplasmic reticulum $\mathrm{Ca}^{2+}$-ATPase vesicles}

All reagents used for the preparation of the calcium pump vesicles were purchased from Sigma-Aldrich (Portugal). Isolated sarcoplasmic reticulum vesicles (SRVs), prepared from rabbit skeletal muscles as described elsewhere, ${ }^{33}$ were suspended in

Table 1 Structural/molecular features of the POTs used in this study

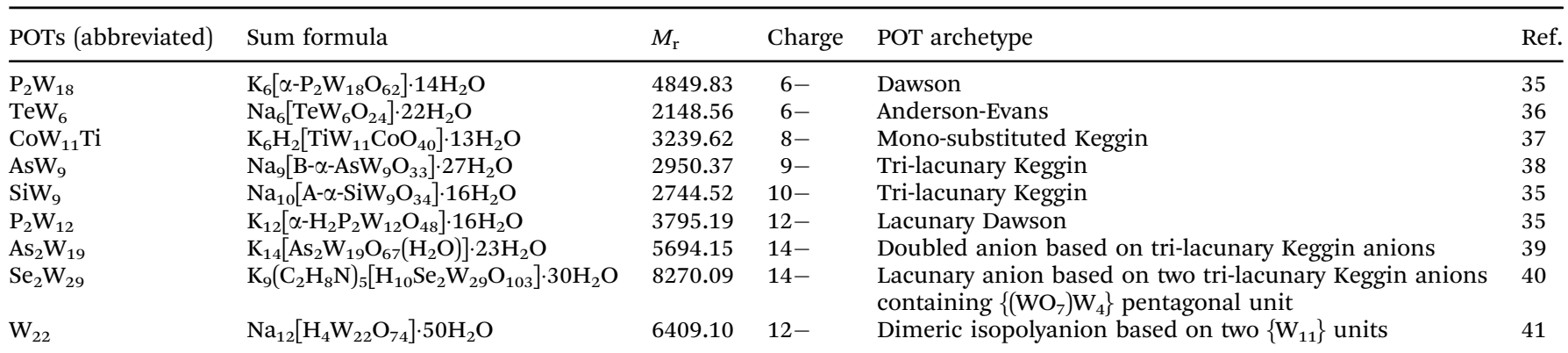


$0.1 \mathrm{M} \mathrm{KCl}, 10 \mathrm{mM}$ HEPES (pH 7.0), diluted 1:1 with 2.0 M sucrose and frozen in liquid nitrogen for storage at $-80{ }^{\circ} \mathrm{C}$. The protein concentration was determined spectrophotometrically at $595 \mathrm{~nm}$ in the presence of $0.125 \%$ of sodium dodecyl sulphate (SDS) by Bradford method with bovine serum albumin as a standard. The percentage of each protein present in the SRV preparations was determined by densitometry analysis of SDS-PAGE (7.5\% acrylamide) protein bands. The SR Ca ${ }^{2+}$-ATPase constituted at least $70 \%$ of the total protein amount in the SR-vesicles according to SDS-PAGE. The sarcoplasmic reticulum $\mathrm{Ca}^{2+}$-ATPase-1 (SERCA-1) was the predominant isoform in our SR preparations. ${ }^{42}$

\section{Effects of POTs on ATP hydrolysis of SR $\mathrm{Ca}^{2+}$-ATPase}

Steady-state assays of the SR $\mathrm{Ca}^{2+}$-ATPase were measured spectrophotometrically at $25{ }^{\circ} \mathrm{C}$ using the coupled enzyme pyruvate kinase/lactate dehydrogenase assay (Scheme 1) as described elsewhere. ${ }^{42}$ Briefly, after the addition of the enzymes (pyruvate kinase and lactate dehydrogenase) and the substrate phosphoenolpyruvate to the medium, the experiment was initiated by adding $\mathrm{NADH}(0.25 \mathrm{mM})$ and the vesicles containing $\mathrm{Ca}^{2+}$-ATPase $\left(10 \mu \mathrm{g} \mathrm{mL}{ }^{-1}\right)$.

ATP (2.5 mM) was added and the absorbance was recorded for about 1 minute (basal activity). Afterwards, the calcium ionophore calcimycin $4 \%(\mathrm{w} / \mathrm{w})$, which releases again the $\mathrm{Ca}^{2+}$ ions, that were pumped in by the ATPase, was added and the decreasing $\mathrm{NADH}$ absorbance at $340 \mathrm{~nm}$ was measured for about 2 minutes (uncoupled ATPase activity). This was done to increase the ATPase activity (due to the ionophore-mediated impairment of the $\mathrm{Ca}^{2+}$ gradient) in order to better study the effect of the inhibitors and to ensure that the SR $\mathrm{Ca}^{2+}$-ATPase vesicles are not leaky. For the experiments including POTs, freshly prepared POT solutions $(10 \mathrm{mM}$ and $1 \mathrm{mM}$ for all POTs except for $\mathrm{Se}_{2} \mathrm{~W}_{29} 1 \mathrm{mM}$ and $0.1 \mathrm{mM}$ ) were added to the medium prior to the addition of SR $\mathrm{Ca}^{2+}$-ATPase. The ATPase activity and its inhibition was measured taking into account the decrease of the OD (optical density) per minute in the absence $(100 \%)$ and in the presence of the investigated POTs. ${ }^{33}$ The detection system was not affected by the POTs themselves (not even at their highest concentrations), which was confirmed by a rapid decrease in absorbance at $340 \mathrm{~nm}$ upon addition of $40 \mu \mathrm{M}$ ADP after the assay. All experiments were performed at least in triplicates. The inhibitory power of the investigated

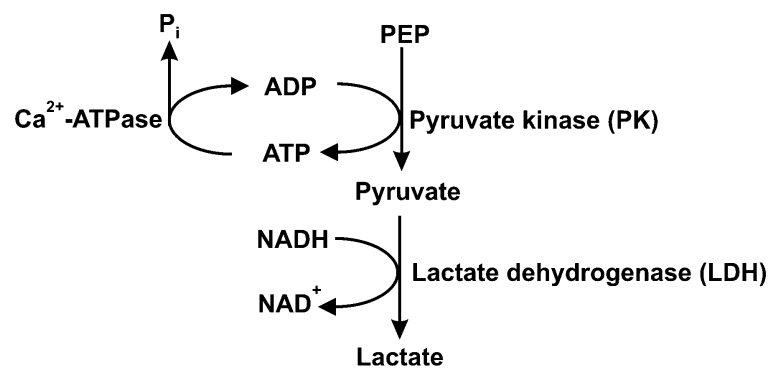

Scheme 1 Coupled enzymatic assay for $\mathrm{Ca}^{2+}$-ATPase activity. PEP phosphoenolpyruvate; $\mathrm{P}_{\mathrm{i}}$ - inorganic phosphate.
POTs was evaluated by determining the respective $\mathrm{IC}_{50}$ value, that is, the POT concentration needed to induce a $50 \%$ inhibition of the $\mathrm{Ca}^{2+}$-ATPase enzyme activity.

\section{Animals used for ex vivo studies}

Killifish ( $F$. heteroclitus, 4-8 g) were collected with fish traps from the saltmarshes of Ria Formosa (Faro, Portugal) and maintained in Ramalhete Marine Station (CCMar, University of Algarve, Faro, Portugal) with running seawater (35 ppt) at a density of $<5 \mathrm{~kg} \mathrm{~m}^{-3}, 18-20{ }^{\circ} \mathrm{C}$ and $12: 12 \mathrm{~h}$ light: dark photoperiod. The animals were handfed twice daily (final ratio of $2 \%$ of the body weight) with commercially available dry pellets (Sorgal, Portugal). The fishes were then food deprived for $24 \mathrm{~h}$ before sampling. The animal collections (ICN, Portugal) and the experimental procedures comply with the guidelines of the European Union Council (86/609/EU) for the use of laboratory animals. All animal protocols were performed under a "Group C" license from the Direcção-Geral de Veterinária, Ministério da Agricultura, do Desenvolvimento Rural e das Pescas, Portugal.

\section{Epithelial short circuit current in Ussing chambers ex vivo}

Epithelial tissues can transport ions and generate a transepithelial voltage termed "active transport potential", which is caused by the asymmetric distribution of ion channels and transporters on the apical and basolateral membranes. The net movement of charges from the apical to the basolateral side (and vice versa) generates a voltage equal to the voltage differences between the apical and basolateral membranes. Ex vivo, the short circuit current $\left(I_{\mathrm{sc}}\right)$ is an accurate reflection of the secretory/absorptive capacity of the tissue when short-circuited. In the opercular epithelium of killifish used for our studies, $I_{\mathrm{sc}}$ is a direct measure of apical chloride secretion mediated by chloride channels, which relies on an intact basolateral $\mathrm{Na}^{+} / \mathrm{K}^{+}$-ATPase function. ${ }^{43,44}$

Methodology for the ex vivo opercular epithelia preparation followed our current methods. ${ }^{45}$ Fish were anaesthetized with 2-phenoxyethanol $(1: 2000 \mathrm{v} / \mathrm{v})$, sacrificed by decapitation and the cranium was cut longitudinally. The gills and other tissue remains were removed carefully and the epithelial skin covering the opercular bone were dissected out and transferred to freshgassed saline (99.7:0.3 $\mathrm{O}_{2} / \mathrm{CO}_{2}$ ) with the following composition (all values in $\mathrm{mM}$ ): $\mathrm{NaCl}, 160 ; \mathrm{MgSO}_{4}, 0.93 ; \mathrm{NaH}_{2} \mathrm{PO}_{4}, 3.0 ; \mathrm{CaCl}_{2}$, 1.5; $\mathrm{NaHCO}_{3}, 17.85 ; \mathrm{KCl}, 3.0$; glucose, 5.5; HEPES (pH 7.8), 5.0. The epithelia were overlaid onto a thin bore polythene net, protected between two parafilm gaskets and pinned over the circular aperture of a tissue holder (P2410, $0.20 \mathrm{~cm}^{2}$, Physiological Instruments, San Diego, USA), with the perimeter area lightly greased with vacuum silicone to minimize tissue edge damage. The mounted tissue was positioned between the two halves of the Ussing chamber (P2400, Physiological Instruments, San Diego, USA) with $4 \mathrm{~mL}$ of gassed saline at $22{ }^{\circ} \mathrm{C}$ and gassed with a 99.7: $0.3 \mathrm{O}_{2} / \mathrm{CO}_{2}$ mix to provide oxygenation, good mixing by gas lift and $\mathrm{pH}$ control $(\mathrm{pH}=7.8)$.

The preparations were left to stand for at least $60 \mathrm{~min}$ or until a steady basal measurement of bioelectrical variables was achieved. Measurement of the short circuit current $\left(I_{\mathrm{sc}}, \mu \mathrm{A} \mathrm{cm}^{-2}\right)$ was performed at symmetric conditions under voltage clamp 

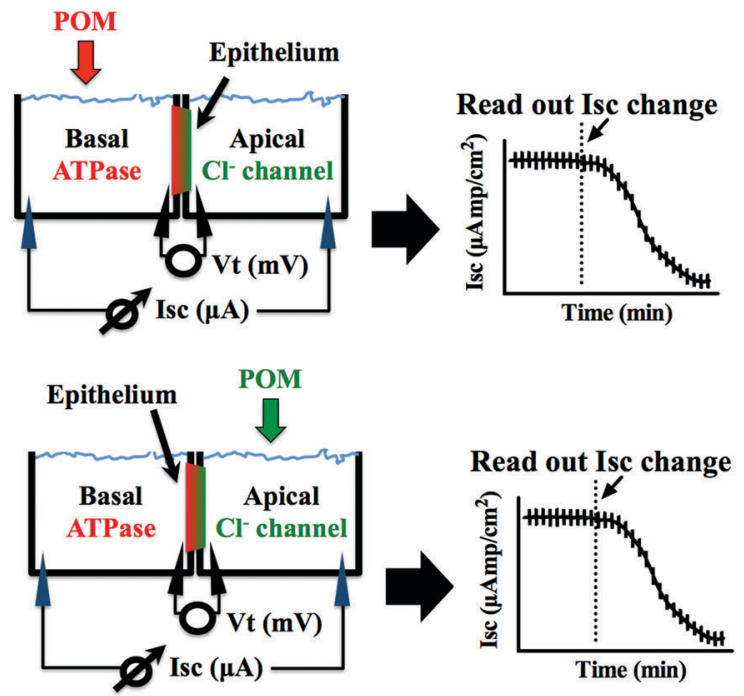

Fig. 2 Graphic representation of the experimental setup of the opercular epithelium of killifish used for ex vivo studies. $I_{\mathrm{sc}}$ was measured in voltage clamp, and in this model represents chloride secretion. The process is energized by basolateral $\mathrm{Na}^{+} / \mathrm{K}^{+}$-ATPase and chloride is secreted apically via a chloride channel. In this polarised epithelium, both mechanisms are required to be intact to sustain the process of secretion.

to $0 \mathrm{mV}$. The open circuit potential $\left(V_{\mathrm{t}}, \mathrm{mV}\right)$ and $I_{\mathrm{sc}}$ were monitored by means of $\mathrm{Ag} / \mathrm{AgCl}$ electrodes connected to the chambers by $3 \mathrm{~mm}$ bore agar bridges ( $1 \mathrm{M} \mathrm{KCl}$ in $3 \%$ agar). Clamping of epithelia to $0 \mathrm{mV}$ and recording of $I_{\mathrm{sc}}$ was performed by VCC600 voltage clamp amplifiers (Physiologic Instruments, San Diego, USA). Epithelial resistance $\left(R_{\mathrm{t}}, \Omega \mathrm{cm}^{2}\right)$ was manually calculated (Ohm's law) using the current deflections induced by bilateral $1 \mathrm{mV}$ pulses of $3 \mathrm{~s}$ every minute. Bioelectrical data were continuously digitized through a Lab-Trax-4 (WPI, Sarasota, US) onto a Macbook laptop using Labscribe3 Software (Iworks systems, Dover, US). Upon signal baseline stabilization, freshly prepared POT solutions were added to the basal or the apical side of the chamber (Fig. 2) and the effects on the $\mathrm{Na}^{+} / \mathrm{K}^{+}$-ATPase from basal membrane or the chloride channel forming the apical membrane were followed for 60 to 90 minutes. The maximum inhibitory effect (in \%) of the POTs on the ATPase activity and the effective time $\left(\mathrm{ET}_{50}\right)$, which is the time necessary to reach $50 \%$ of the maximum effects (in minutes), was determined by measuring the \% decrease of short circuit current $\left(I_{\mathrm{sc}}, \mu \mathrm{A} \mathrm{cm}{ }^{-2}\right)$ in the absence $(100 \%$ activity) and presence of the POTs. All the experiments were performed at least in triplicates. Calculations of the $\mathrm{ET}_{50}$ and maximum effect values were performed using GraphPad Prism version 6.00 for Macintosh (GraphPad Software, La Jolla California USA).

\section{Results and discussion}

\section{Inhibition of $\mathrm{Ca}^{2+}$-ATPase by POTs: in vitro study}

The effect of nine different POTs (Fig. 1 and Table 1) on the activity of SR $\mathrm{Ca}^{2+}$-ATPase from skeletal muscle was investigated for the first time. All of the investigated POTs inhibited $\mathrm{Ca}^{2+}$-ATPase activity in a concentration dependent manner. The inhibitory power
Table 2 Inhibitory parameters of the POTs for SR Ca ${ }^{2+}$-ATPase $\left(\mathrm{IC}_{50}\right.$ values) activity and $\mathrm{Na}^{+} / \mathrm{K}^{+}$-ATPase activity from basal membrane epithelia (effective time $50 \mathrm{ET}_{50}$ and maximum inhibitory effects are calculated as the \% of basal values). Inhibitory effect of different POTs applied basolaterally to the ex vivo preparation of the opercular epithelia of killifish mounted in Ussing chambers. Results are representative values for 3 independent experiments for each concentration (nd: not determined as no effect was observed after 30 minutes upon POT addition). Data showing the effect of ouabain for the $\mathrm{Na}^{+} / \mathrm{K}^{+}$-ATPase inhibition is included as a positive control for the ex vivo system

\begin{tabular}{|c|c|c|c|}
\hline \multirow{2}{*}{$\begin{array}{l}\text { POTs } \\
\begin{array}{l}\text { Compound } \\
\text { name }\end{array}\end{array}$} & \multirow{2}{*}{$\begin{array}{l}\underline{\mathrm{Ca}^{2+}-\mathrm{ATPase}} \\
\mathrm{IC}_{50},(\mu \mathrm{M})\end{array}$} & \multicolumn{2}{|l|}{$\underline{\mathrm{Na}^{+} / \mathrm{K}^{+} \text {-ATPase }}$} \\
\hline & & $\begin{array}{l}\mathrm{ET}_{50},(\text { min }(\text { depending } \\
\text { on concentration of } \\
\text { compound)) }\end{array}$ & $\begin{array}{l}\text { Maximum } \\
\text { inhibition, (\%) }\end{array}$ \\
\hline \multirow[t]{3}{*}{$\mathrm{P}_{2} \mathrm{~W}_{18}$} & 0.6 & $8.2(0.5 \mu \mathrm{M})$ & 86 \\
\hline & & $6.5(1 \mu \mathrm{M})$ & 99 \\
\hline & & $4.3(10 \mu \mathrm{M})$ & 100 \\
\hline $\mathrm{TeW}_{6}$ & 200 & $60(10 \mu \mathrm{M})$ & 10 \\
\hline $\mathrm{CoW}_{11} \mathrm{Ti}$ & 4 & $10(10 \mu \mathrm{M})$ & 75 \\
\hline $\mathrm{SiW}_{9}$ & 16 & nd & nd \\
\hline $\mathrm{P}_{2} \mathrm{~W}_{12}$ & 11 & nd & nd \\
\hline $\mathrm{As}_{2} \mathrm{~W}_{19}$ & 28 & nd & nd \\
\hline $\mathrm{Se}_{2} \mathrm{~W}_{29}$ & 0.3 & $6.5(1 \mu \mathrm{M})$ & 14 \\
\hline $\mathrm{W}_{22}$ & 68 & nd & nd \\
\hline $\mathrm{AsW}_{9}$ & 20 & $8.5(10 \mu \mathrm{M})$ & 66 \\
\hline Ouabain & - & $3.2(10 \mu \mathrm{M})$ & 100 \\
\hline
\end{tabular}

of the investigated POTs was finally evaluated using $\mathrm{IC}_{50}$ values (Table 2). As shown in Table 2, different $\mathrm{IC}_{50}$ values in the $\mu \mathrm{M}$ range were determined for the various POT archetypes exhibiting different negative charges (Fig. 1 and Table 1 ). $\mathrm{IC}_{50}$ values of $<1 \mu \mathrm{M}$ were determined for the Dawson anion $\mathrm{P}_{2} \mathrm{~W}_{18}(0.6 \mu \mathrm{M}$, Fig. 3$)$ and the larger POT $\mathrm{Se}_{2} \mathrm{~W}_{29}\left(\mathrm{IC}_{50}=0.3 \mu \mathrm{M}\right)$, whereas the lowest inhibition values were observed for the isopolyanion $\mathrm{W}_{22}\left(\mathrm{IC}_{50}=68 \mu \mathrm{M}\right)$ and the Anderson type $\mathrm{TeW}_{6}\left(\mathrm{IC}_{50}=200 \mu \mathrm{M}\right)$. The remaining POTs exhibited $\mathrm{IC}_{50}$ values in the range of 1 up to $28 \mu \mathrm{M}$ (Table 2).

Similar moderate $\mathrm{IC}_{50}$ values for $\mathrm{SR} \mathrm{Ca}^{2+}$-ATPase activity were previously reported for two isostructural polyanions, decaniobate $\left[\mathrm{Nb}_{10} \mathrm{O}_{28}\right]^{6-}\left(\mathrm{IC}_{50}=35 \mu \mathrm{M}\right)$ and decavanadate $\left[\mathrm{V}_{10} \mathrm{O}_{28}\right]^{6-}\left(\mathrm{IC}_{50}=15 \mu \mathrm{M}\right){ }^{33,46}$ Both decaniobate and decavanadate showed a non-competitive inhibition for $\mathrm{Ca}^{2+}$-ATPase activity

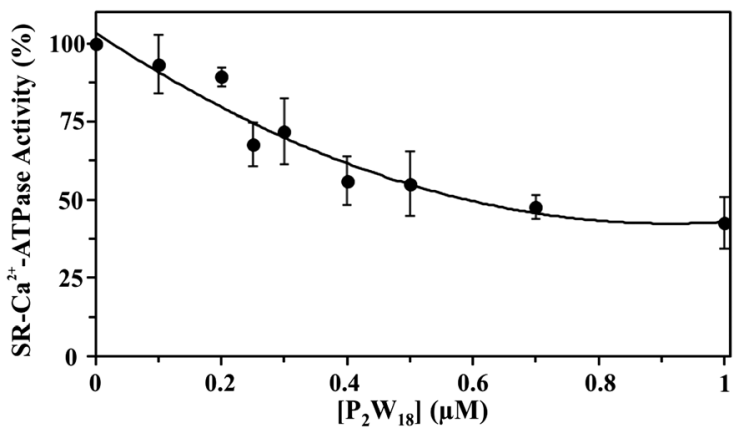

Fig. 3 Inhibition of $\mathrm{Ca}^{2+}$-ATPase activity by $\mathrm{P}_{2} \mathrm{~W}_{18} \cdot \mathrm{Ca}^{2+}$-ATPase was determined spectrophotometrically at $340 \mathrm{~nm}$ and $25^{\circ} \mathrm{C}$, using the coupled enzyme pyruvate kinase/lactate dehydrogenase assay. The experiments were initiated by the addition of $10 \mu \mathrm{g} \mathrm{mL}^{-1} \mathrm{Ca}^{2+}$-ATPase, in the presence or absence of $4 \%(\mathrm{w} / \mathrm{w})$ of the calcium ionophore calcimycin. Data are plotted as means \pm SD and fit to the equation $y=73.126 x^{2}-133.62 x+$ $103.45\left(R^{2}=0.9424\right)$. 


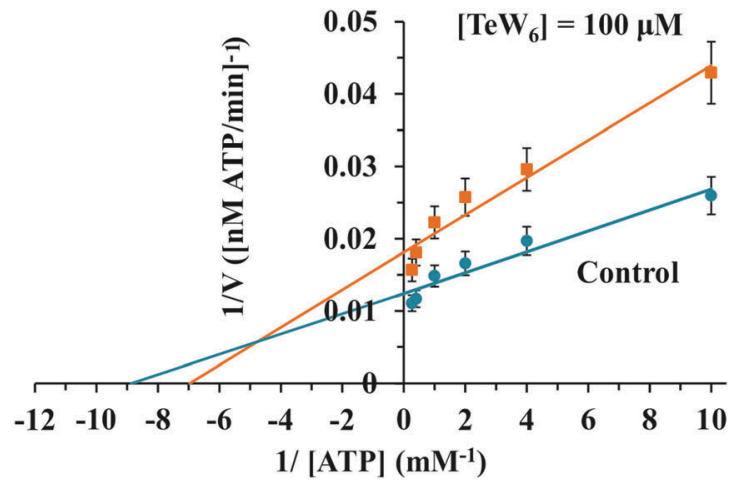

Fig. 4 Lineweaver-Burk plots of $\mathrm{Ca}^{2+}$-ATPase activity in the absence (blue) and in the presence (orange) of $100 \mu \mathrm{M} \mathrm{TeW}_{6}$. The Anderson type $\mathrm{TeW}_{6}$ presented a mixed type of enzyme inhibition. Data are plotted as means \pm SD. The equations for linear fits are $y=0.0014 x+0.0124$ $\left(R^{2}=0.9333\right)$ for control and $y=0.0026 x+0.0181\left(R^{2}=0.955\right)$ for TeW 6 . The results shown are the average of triplicate experiments.

regarding the natural ligand MgATP. ${ }^{33}$ Thus, to further investigate the kind of interactions between the POTs and ATPase, the type of inhibition was determined for $\mathrm{P}_{2} \mathrm{~W}_{18}$ and $\mathrm{TeW}_{6}$. It was observed that both $\mathrm{P}_{2} \mathrm{~W}_{18}$ (data not shown) and $\mathrm{TeW}_{6}$ exhibited a mixed type inhibition suggesting that they can interact with the substratebound form of $\mathrm{Ca}^{2+}$-ATPase (Fig. 4). The binding site of $\mathrm{V}_{10}$ on $\mathrm{Ca}^{2+}$-ATPase was previously described, which involves at least three protein domains, including the phosphorylation and the nucleotide binding sites. ${ }^{47}$

\section{Inhibition of $\mathrm{Na}^{+} / \mathrm{K}^{+}$-ATPase by POTs: ex vivo study}

POTs were added to the basolateral side of epithelia (Fig. 2) to characterize their effects on the $\mathrm{Na}^{+} / \mathrm{K}^{+}$-ATPase activity. The obtained results, which are summarized in Table 2 , revealed inhibition rates ranging from only $10 \%$ for $\mathrm{TeW}_{6}$ (at $10 \mu \mathrm{M}$ ) to almost $100 \%$ for $\mathrm{P}_{2} \mathrm{~W}_{18}$ (at 1 and $10 \mu \mathrm{M}$ ).

It should be noted that the heteropoly POTs $\mathrm{SiW}_{9}, \mathrm{P}_{2} \mathrm{~W}_{12}$, $\mathrm{As}_{2} \mathrm{~W}_{19}$ as well as the isopoly POT $\mathrm{W}_{22}$ showed no effect on ATPase activity after 30 minutes upon addition of $10 \mu \mathrm{M}$ compound. In order to further characterize the inhibitory effects of the investigated POTs on $\mathrm{Na}^{+} / \mathrm{K}^{+}$-ATPase, we calculated the maximum inhibitory effects with respect to the basal values. In addition, we calculated the effective time $\left(\mathrm{ET}_{50}\right)$, defined as the time necessary to achieve $50 \%$ of the maximum effect, to have a measure for the inhibitory dynamics of the individual POTs (Fig. 5). In Fig. 5 a constant height of the current deflections used to calculate the tissue resistance can be observed, indicating that the ex vivo preparations retained their integrity and selectivity before and after POT exposure. Therefore, since no changes were observed on the tissue resistance (i.e. tissue integrity) all observed effects of POT on the epithelial function are due to changes of the short circuit current $\left(I_{\mathrm{sc}}\right)$. Modification of $I_{\mathrm{sc}}$ provides an immediate read-out of inhibitory/stimulatory effects on either the apical chloride channel or the basolateral $\mathrm{Na}^{+} / \mathrm{K}^{+}$-ATPase (Fig. 2). For example, $\mathrm{AsW}_{9}($ at $10 \mu \mathrm{M})$ exhibits a maximum inhibition of $66 \%$ of the basal current and an $\mathrm{ET}_{50}$ value of 8.5 min (Fig. 5). It has to be noted that both the maximum inhibitory effect

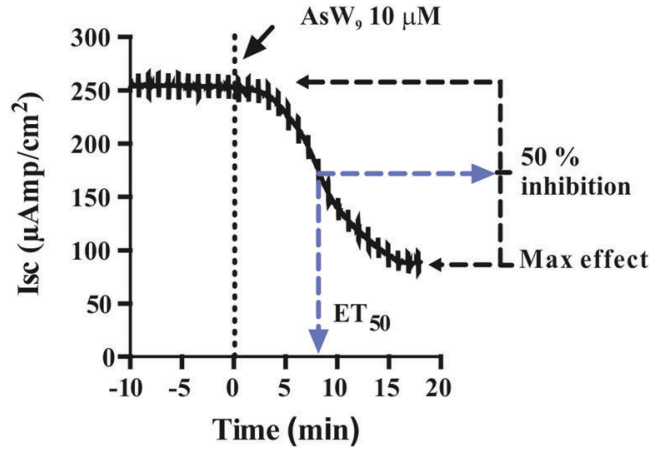

Fig. 5 The effect of the Keggin type $\mathrm{AsW}_{9}$ applied in basolateral membranes at a concentration of $10 \mu \mathrm{M}$ is shown. Original trace of the effect of short circuit current $\left(I_{\mathrm{sc}}, \mu \mathrm{A} \mathrm{cm}{ }^{-2}\right)$ in the opercular epithelium of killifish mounted in Ussing chambers and kept under voltage clamp $\left(V_{t}=0 \mathrm{mV}\right)$. Effective time $50\left(E_{50}\right)$ and maximum inhibitory effects are calculated as the \% of basal values. Both parameters were calculated for three individual independent experiments and used to generate Table 2. An arrow indicates the time of POT application and consequently the time point zero. Time with negative values represents stable basal control periods.

(providing information about inhibitor efficacy) and $\mathrm{ET}_{50}$ (providing information about inhibition velocity) are necessary to define the biological effects of POTs (Fig. 5 and Table 2). For the ex vivo studies, a positive control experiment was performed with the conventional $\mathrm{Na}^{+} / \mathrm{K}^{+}$-ATPase inhibitor ouabain. ${ }^{43,49}$ Ouabain (at $10 \mu \mathrm{M}$ ) showed a maximum inhibition value of $100 \%$ and an $\mathrm{ET}_{50}$ of 3.2 minutes (Fig. S1, ESI $\dagger$ ). By inhibiting the basolateral $\mathrm{Na}^{+} / \mathrm{K}^{+}$-ATPase activity, ouabain concomitantly prevents apical chloride secretion in the studied epithelia model as this process is energized by $\mathrm{Na}^{+} / \mathrm{K}^{+}$-ATPase. ${ }^{43,49}$

The addition of POTs to apical saline had no effect on $I_{\mathrm{sc}}$ and therefore ruling out chloride channels as putative POT targets, at least at POT concentrations up to $10 \mu \mathrm{M}$. The largest POT (in terms of volume and number of addenda atoms) under investigation, $\mathrm{Se}_{2} \mathrm{~W}_{29}$, exhibited the highest inhibition $\left(\mathrm{IC}_{50}=\right.$ $0.3 \mu \mathrm{M}$ ) of SR $\mathrm{Ca}^{2+}$-ATPase activity during the in vitro study. However, used at the same concentration $(1 \mu \mathrm{M})$, it was one of the weakest inhibitors (14\% inhibition; Table 2 and Fig. 6) for the $\mathrm{Na}^{+} / \mathrm{K}^{+}$-ATPase activity during the ex vivo study. In contrast, $\mathrm{P}_{2} \mathrm{~W}_{18}$ efficiently inhibited both the $\mathrm{SR} \mathrm{Ca}^{2+}$-ATPase in vitro $\left(\mathrm{IC}_{50}=0.6 \mu \mathrm{M}\right)$ and the $\mathrm{Na}^{+} / \mathrm{K}^{+}$-ATPase ex vivo (99\% inhibition) (Table 2 and Fig. 6). In fact, $\mathrm{P}_{2} \mathrm{~W}_{18}$ was demonstrated to be as potent as ouabain in inhibiting the $\mathrm{Na}^{+} / \mathrm{K}^{+}$-ATPase activity (Table 2). The remaining studied POTs showed similar inhibitory effects in vitro and ex vivo. For example, the potential of $\mathrm{TeW}_{6}$ to inhibit $\mathrm{Ca}^{2+}$-ATPase ( $\mathrm{IC}_{50}$ value of $200 \mu \mathrm{M}$ ) was as low as its effect against $\mathrm{Na}^{+} / \mathrm{K}^{+}$-ATPase (inhibition of $10 \%$; Table 2 ).

Both experiments (in vitro and ex vivo) clearly demonstrated the high selectivity of $\mathrm{Se}_{2} \mathrm{~W}_{29}$ for inhibiting the $\mathrm{Ca}^{2+}$ pump due to its rather sobering ex vivo results rendering this POT not the best choice to target the $\mathrm{Na}^{+} / \mathrm{K}^{+}$-pump in vivo. The size (in terms of volume and number of addenda atoms) of this large POT could be one aspect affecting the kinetics of its cellular uptake, thus preventing the POT from targeting the enzyme. The mechanisms of POT uptake and their permeation through 


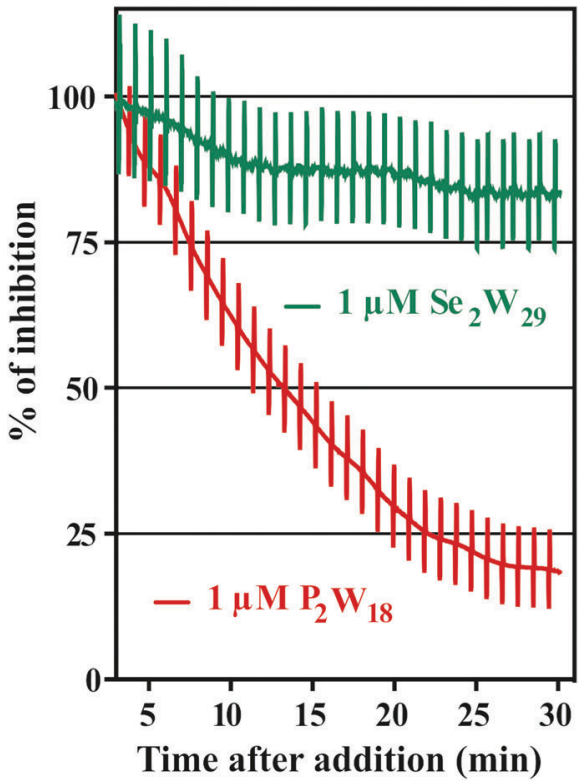

Fig. 6 Inhibition (\%) of the $\mathrm{Na}^{+} / \mathrm{K}^{+}$-ATPase from basal membrane of the skin epithelia by two POTs $\mathrm{P}_{2} \mathrm{~W}_{18}$ and $\mathrm{Se}_{2} \mathrm{~W}_{29}$. The inhibition rate of $\mathrm{P}_{2} \mathrm{~W}_{18}$ $(1 \mu \mathrm{M})$ was $82 \%$ after 30 minutes (red), whereas for the most potent $\mathrm{Ca}^{2+}$-ATPase inhibitor so far described, $\mathrm{Se}_{2} \mathrm{~W}_{29}\left(\mathrm{IC}_{50}=0.3 \mu \mathrm{M}\right)$, a minor effect (green) was observed (14\% inhibition, after 30 minutes). Perpendicular lines were used to calculate tissue resistance. As it can be observed, the ex vivo epithelia preparations retained integrity and selectivity after POT exposure.

epithelia still need to be clarified. The same selectivity pattern

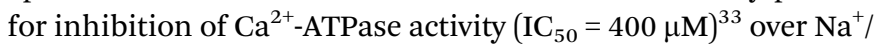
$\mathrm{K}^{+}$-ATPase $\left(\mathrm{IC}_{50}=1.5 \mathrm{mM}\right)^{34}$ was shown in previous studies for orthotungstate $\left(\mathrm{HWO}_{4}{ }^{-}\right)$. Therefore, it seems that POT-mediated inhibition is pump-specific and there is no POT structure that is perfectly suited for all ion pumps in general. Moreover, the ex vivo results show that not only the affinity of the inhibitory compound is relevant, but also how the POT gains access to the inhibition site within an intracellular compartment, rendering the POT- $\mathrm{Na}^{+} /$ $\mathrm{K}^{+}$-ATPase interaction a complex one. The presented combination of in vitro and ex vivo studies using two different models to study the effects of POTs on the activity of ATPases indicates the importance of establishing experimental conditions to be as close to the physiological environment as possible.

The majority of P-type ATPase inhibitors in therapy target the $\mathrm{Na}^{+} / \mathrm{K}^{+}$-ATPase. ${ }^{32,48}$ These compounds, which are used for the treatment of several diseases such as heart failure, psychosis, malaria and bacterial infection, show inhibitory capacities resembling those of the here investigated POTs. ${ }^{48}$ Only a few kinetic studies have been described so far testing POTs as P-type ATPase inhibitors. ${ }^{24,32,42,46}$ The in vitro inhibition of $\mathrm{Na}^{+} / \mathrm{K}^{+}$-ATPase by the Keggin POTs $\mathrm{H}_{3} \mathrm{PW}_{12} \mathrm{O}_{40}$ and $\mathrm{H}_{4} \mathrm{SiW}_{12} \mathrm{O}_{40}$ was previously described reporting $\mathrm{IC}_{50}$ values between 3 to $4 \mu \mathrm{M}^{32}$ although information about the type of inhibition and the mechanism of action are still lacking. In this study the comparable $\mathrm{IC}_{50}$ value for the isostructural Keggin POT $\mathrm{CoW}_{11} \mathrm{Ti}\left(\mathrm{IC}_{50}=4 \mu \mathrm{M}\right)$ was observed.

\section{Protein interactions and structure/function features of POTs}

In order to decipher specific features of the nine POTs that are responsible for the inhibition of $\mathrm{Ca}^{2+}$-ATPase, we correlated the POT parameters like size and charge density with their $\mathrm{IC}_{50}$ values of inhibition (Fig. 7A and B). No correlation was found when considering all nine POTs and thus all determined $\mathrm{IC}_{50}$ values. However, when taking only into account the high affinity POTs, exhibiting $\mathrm{IC}_{50}$ values lower then $16 \mu \mathrm{M}$, we observed a correlation between their activity $\left(\mathrm{IC}_{50}\right.$ value) and their charge density, which was defined as charge of the POT divided by its number of $\mathrm{W}$ atoms (Fig. 7A) as well as by the volume of POT anion (Fig. 7B). As can be deduced from this data, POTs such as $\mathrm{Se}_{2} \mathrm{~W}_{29}$ and $\mathrm{P}_{2} \mathrm{~W}_{18}$ with a low charge density (Fig. 7A and B) favored the inhibition of $\mathrm{Ca}^{2+}$-ATPase activity indicating that besides electrostatic interactions also steric interactions (depending on the shape complementarity between the POT and the inhibition site) might play important roles in the successful inhibition of $\mathrm{Ca}^{2+}$-ATPase.

For the ex vivo results $\left(\mathrm{Na}^{+} / \mathrm{K}^{+}\right.$-ATPase $)$no correlation between the $\mathrm{ET}_{50}$ values and POT charge density was observed.
A

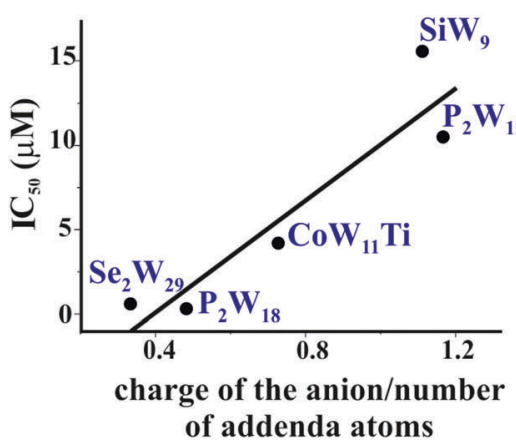

B

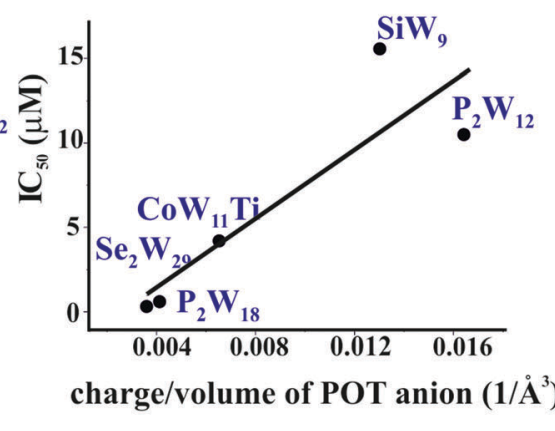

C

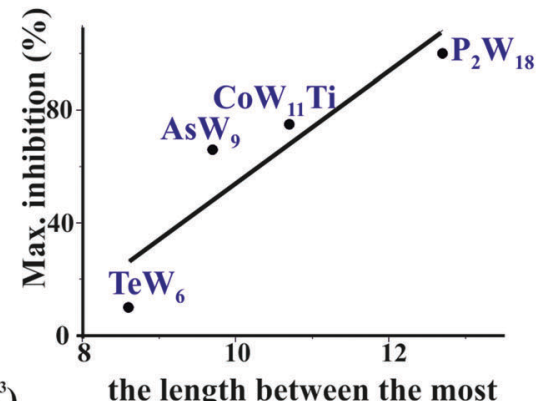
distant atoms in the POT anion, $(\AA)$

Fig. 7 Structure-activity correlations of different POTs for ATPases inhibition. (A) Correlation between the IC $\mathrm{C}_{50}$ values of five POTs $\left(\mathrm{IC}_{50}\right.$ lower then $16 \mu \mathrm{M}$ ) of $\mathrm{Ca}^{2+}$-ATPase inhibition and their charge density expressed as charge of the POT divided by its number of W atoms. (B) Correlation between the $I C_{50}$ values of five POTs $\left(\mathrm{IC}_{50}\right.$ lower then $\left.16 \mu \mathrm{M}\right)$ against $\mathrm{Ca}^{2+}$-ATPase and the charge density expressed as charge of the POT divided by its volume (in $\AA^{-3}$ ). (C) Correlation between the percentage of maximum inhibition of four POTs (applied with the same concentration of $10 \mu M$ ) against $\mathrm{Na}^{+} / \mathrm{K}^{+}$-ATPase and POT size expressed as the length between the most distant atoms in the POT anion (in $\AA$ ). 

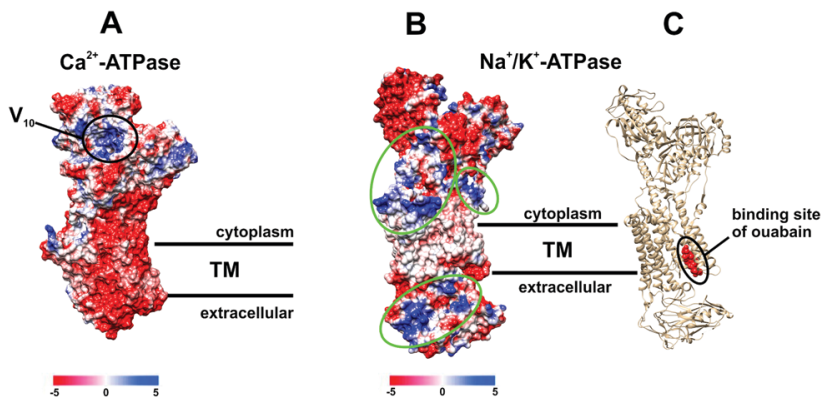

Fig. 8 Electrostatic (Coulomb) potential surface presentation (scale in kcal mol ${ }^{-1} \mathrm{e}^{-1}, \mathrm{TM}$ - transmembrane area) of two P-type ATPases: (A) $\mathrm{Ca}^{2+}$-pump in $\mathrm{E} 2$ conformation ${ }^{31,32}$ (PDB entry: $1 \mathrm{KJU}$ ) showing the proposed binding site of decavanadate $\mathrm{V}_{10} ;{ }^{47}$ (B) electronic (coulombic) surface representation of the $\mathrm{Na}^{+} / \mathrm{K}^{+}$-pump (green circles indicate potential binding sites for POMs); (C) structure of the $\mathrm{Na}^{+} / \mathrm{K}^{+}$-ATPase-ouabain complex ${ }^{31}$ (PDB entry: 3A3Y). $\mathrm{Na}^{+} / \mathrm{K}^{+}$-ATPase is illustrated as beige cartoon, whereas bound ouabain is depicted in sphere mode.

However, a dependency of the maximum inhibition of four POTs on their size, defined as length between the most distant atoms in the POT anion was found (Fig. 7C).

POTs are also known to be strong kinase and phosphatase inhibitors by acting through noncovalent interactions, which is indispensable for the usage of POMs in the therapy of various diseases. ${ }^{17-19,26,27}$ It was demonstrated that decavanadate $V_{10}$ exhibits specific interactions with SR $\mathrm{Ca}^{2+}$-ATPase, which is supposed to be non-competitive with respect to ATP and induces protein cysteine oxidation with concomitant vanadium reduction explaining the high inhibitory capacity of $\mathrm{V}_{10}\left(\mathrm{IC}_{50}=\right.$ $15 \mu \mathrm{M}){ }^{24,33,47,48}$ The $\mathrm{V}_{10}$ binding site, which is formed by three protein domains, ${ }^{47}$ is located at the cell cytoplasmatic side (Fig. 8A). $\mathrm{V}_{10}$ can interact with proteins by electrostatic interactions or by hydrogen bonding and the specific residues involved in $\mathrm{V}_{10}$-SR $\mathrm{Ca}^{2+}$-ATPase interaction still need to be established, but might include the oxidized cysteine. ${ }^{24}$ In contrast to monomeric vanadate, which only binds to the E2 conformation, $\mathrm{V}_{10}$ binds to all protein conformations, E1, E1P, $\mathrm{E} 2$ and $\mathrm{E} 2 \mathrm{P},{ }^{33}$ indicating the possibility of $\mathrm{V}_{10}$-ATPase interactions at the extracellular side of the enzyme. ${ }^{48}$ The region where $V_{10}$ is expected to bind exhibits a positively charged surface and could therefore also be addressed by other negatively charged POMs (Fig. 8A).

Many drugs are known to act as ionic pumps inhibitors, such as ouabain, omeprazole or thapsigargin, but only for some of these compounds like ouabain the mechanisms and protein binding sites were clearly established. ${ }^{32}$ According to structural analysis, ouabain inhibits the $\mathrm{Na}^{+} / \mathrm{K}^{+}$-ATPase through binding to a cavity formed by transmembrane helices (Fig. 8C, PDB entry: $3 \mathrm{~A} 3 \mathrm{Y}$ ).$^{32}$ The binding sites for POMs are not known yet, however, considering the structures of POMs and ouabain, it is very unlikely that they share the same binding site (within the neutral transmembrane area). Analysis of the electrostatic (coulombic) surface of $\mathrm{Na}^{+} / \mathrm{K}^{+}$-ATPase reveals that both the cytoplasmic and extracellular region of the enzyme possess areas exhibiting a positive surface potential (Fig. 8B), ${ }^{31}$ which could be addressed by the negatively charged POMs, the binding sites of which need to be identified.

\section{Conclusions}

In general, polyoxometalates are able to inhibit phosphatases, ecto-nucleotidases and P-type ATPases. Here, we demonstrated that the $\mathrm{Ca}^{2+}$-ATPase activity from sarcoplasmic reticulum is inhibited by several POTs. $\mathrm{P}_{2} \mathrm{~W}_{18}$ was the most potent ATPase inhibitor in this study as it exhibited the highest inhibitory activity for the $\mathrm{Na}^{+} / \mathrm{K}^{+}$-ATPase $(100 \%$ inhibition at $10 \mu \mathrm{M})$ and the second highest for the $\mathrm{Ca}^{2+}$-ATPase $\left(\mathrm{IC}_{50}=0.6 \mu \mathrm{M}\right)$. A mixed type of inhibition was observed for $\mathrm{P}_{2} \mathrm{~W}_{18}$ and $\mathrm{TeW}_{6}$ suggesting a different mode of protein interaction with $\mathrm{Ca}^{2+}$-ATPase activity than those observed for decavanadate and decaniobate (noncompetitive inhibitors). The most potent $\mathrm{Ca}^{2+}$-ATPase inhibitor $\mathrm{Se}_{2} \mathrm{~W}_{29}$ showed only limited effects on the $\mathrm{Na}^{+} / \mathrm{K}^{+}$-ATPase from basal membrane of the skin epithelia demonstrating that some POTs exhibit selectivity against certain ion pumps. The here reported ex vivo model of $\mathrm{Na}^{+} / \mathrm{K}^{+}$-ATPase was used for the first time to study the effects of POTs on the processes of epithelial chloride secretion, energized by the activity of the basolateral $\mathrm{Na}^{+} / \mathrm{K}^{+}$-ATPase. Finally, we were able to derive structure-activity relationships for high affinity POTs $\left(\mathrm{IC}_{50}<16 \mu \mathrm{M}\right)$ indicating that the inhibition potential of the POTs is correlated with their charge density, which will help to clarify their different inhibitory activity. Polyoxotungstates are promising inorganic inhibitors of P-type ATPases although their potential in vivo applications require more studies and toxicological information.

\section{Conflicts of interest}

There are no conflicts to declare.

\section{Acknowledgements}

This research was funded by the Austrian Science Fund (FWF): P27534 (AR), M2203 (NG) and M2200 (LK). MA thanks the national funds through FCT, Foundation for Science and Technology (UID/Multi/04326/2013; SFRH/BSAB/129821/2017). LK acknowledges support from Action Austria - Slovakia Program (Co-operation in Science and Education).

\section{Notes and references}

1 M. T. Pope, Heteropoly and isopoly oxometalates, SpringerVerlag, Berlin, 1983.

2 H. Lv, Y. V. Geletii, C. Zhao, J. W. Vickers, G. Zhu, Z. Luo, J. Song, T. Lian, D. G. Musaev and C. L. Hill, Polyoxometalate water oxidation catalysts and the production of green fuel, Chem. Soc. Rev., 2012, 41, 7572-7589.

3 S. S. Wang and G. Y. Yang, Recent advances in polyoxometalatecatalyzed reactions, Chem. Rev., 2015, 115, 4893-4962.

4 E. Papaconstantinou and A. Hiskia, Photochemistry and Photocatalysis by Polyoxometalates, in Polyoxometalate Molecular 
Science. NATO Science Series (Series II: Mathematics, Physics and Chemistry), ed. J. J. Borrás-Almenar, E. Coronado, A. Müller, M. Pope, Springer, Dordrecht, 2003, vol. 98, pp. 381-416.

5 M. A. Moussawi, N. Leclerc-Laronze, S. Floquet, P. A. Abramov, M. N. Sokolov, S. Cordier, A. Ponchel, E. Monflier, H. Bricout, D. Landy, M. Haouas, J. Marrot and E. Cadot, Polyoxometalate, cationic cluster, and $\gamma$-cyclodextrin: from primary interactions to supramolecular hybrid materials, J. Am. Chem. Soc., 2017, 139, 12793-12803.

6 A. Proust, R. Thouvenot and P. Gouzerh, Functionalization of polyoxometalates: towards advanced applications in catalysis and materials science, Chem. Commun., 2008, 1837-1852.

7 A. Bijelic and A. Rompel, The use of polyoxometalates in protein crystallography-An attempt to widen a well-known bottleneck, Coord. Chem. Rev., 2015, 299, 22-38.

8 A. Bijelic and A. Rompel, Ten Good reasons for the use of the tellurium-centered Anderson-Evans polyoxotungstate in protein crystallography, Acc. Chem. Res., 2017, 50, 1441-1448.

9 C. Molitor, A. Bijelic and A. Rompel, The potential of hexatungstotellurate(vi) to induce a significant entropic gain during protein crystallization, IUCrJ, 2017, 4, 734-740.

10 A. Bijelic, C. Molitor, S. G. Mauracher, R. Al-Oweini, U. Kortz and A. Rompel, Hen egg-white lysozyme crystallisation: protein stacking and structure stability enhanced by a tellurium(vI)-centred polyoxotungstate, ChemBioChem, 2015, 16, 233-241.

11 S. G. Mauracher, C. Molitor, R. Al-Oweini, U. Kortz and A. Rompel, Crystallization and preliminary X-ray crystallographic analysis of latent isoform PPO4 mushroom (Agaricus bisporus) tyrosinase, Acta Crystallogr., 2014, F70, 263-266.

12 S. G. Mauracher, C. Molitor, R. Al-Oweini, U. Kortz and A. Rompel, Latent and active $a b \mathrm{PPO} 4$ mushroom tyrosinases cocrystallized with hexatungstotellurate(vi) in a single crystal, Acta Crystallogr., 2014, D70, 2301-2315.

13 C. Molitor, S. G. Mauracher and A. Rompel, Crystallization and preliminary crystal structure analysis of latent, active and recombinantly expressed aurone synthase - a polyphenol oxidase - from Coreopsis grandiflora, Acta Crystallogr., 2015, F71, 746-751.

14 C. Molitor, S. G. Mauracher and A. Rompel, Aurone synthase is a catechol oxidase with hydroxylase activity and provides insights into the mechanism of plant polyphenol oxidases, Proc. Natl. Acad. Sci. U. S. A., 2016, 113, E1806-E1815.

15 C. Molitor, A. Bijelic and A. Rompel, In situ formation of the first proteinogenically functionalized $\left[\mathrm{TeW}_{6} \mathrm{O}_{24} \mathrm{O}_{2}(\mathrm{Glu})\right]^{7-}$ structure reveals unprecedented chemical and geometrical features of the Anderson-type cluster, Chem. Commun., 2016, 52, 12286-12289.

16 B. Hasenknopf, Polyoxometalates: introduction to a class of inorganic compounds and their biomedical applications, Front. Biosci., 2005, 10, 275-287.

17 T. Yamase, Polyoxometalates active against tumors, viruses, and bacteria, in Biomedical Inorganic Polymers, ed. W. E. G. Müller, X. Wang, H. C. Schröder, Springer, Berlin, Heidelberg, Mainz, 2013, pp. 65-116.
18 H. Stephan, M. Kubeil, F. Emmerling and C. E. Müller, Polyoxometalates as versatile enzyme inhibitors, Eur. J. Inorg. Chem., 2013, 1585-1594.

19 S. Y. Lee, A. Fiene, W. Li, T. Hanck, K. A. Brylev, V. E. Fedorov, J. Lecka, A. Haider, H. J. Pietzsch, H. Zimmermann, J. Sévigny, U. Kortz, H. Stephan and C. E. Müller, Polyoxometalates-potent and selective ecto-nucleotidase inhibitors, Biochem. Pharmacol., 2015, 93, 171-181.

20 H. U. V. Gerth, A. Rompel, B. Krebs, J. Boos and C. LanversKaminsky, Cytotoxic effects of novel polyoxotungstates and a platinum compound on human cancer cell lines, Anti-Cancer Drugs, 2005, 16, 101-106.

21 A. Galani, V. Tsitsias, D. Stellas, V. Psycharis, C. P. Raptopoulou and A. Karaliota, Two novel compounds of vanadium and molybdenum with carnitine exhibiting potential pharmacological use, J. Inorg. Biochem., 2015, 142, 109-117.

22 S. Treviño, D. Velázquez-Vázquez, E. Sánchez-Lara, A. DiazFonseca, J. A. Flores-Hernandez, A. Pérez-Benítez, E. BrambilaColombres and E. González-Vergara, Metforminium decavanadate as a potential metallopharmaceutical drug for the treatment of diabetes mellitus, Oxid. Med. Cell. Longevity, 2016, 6058705.

23 T. L. Turner, V. H. Nguyen, C. C. McLauchlan, Z. Dymon, B. M. Dorsey, J. D. Hooker and M. A. Jones, Inhibitory effects of decavanadate on several enzymes and Leishmania tarentolae in vitro, J. Inorg. Biochem., 2012, 108, 96-104.

$24 \mathrm{M}$. Aureliano, Decavanadate toxicology and pharmacological activities: $\mathrm{V}_{10}$ or $\mathrm{V}_{1}$, Both or None?, Oxid. Med. Cell. Longevity, 2016, 6103457.

25 F. Zhai, X. Wang, D. Li, H. Zhang, R. Li and L. Song, Synthesis and biological evaluation of decavanadate $\mathrm{Na}_{4} \mathrm{Co}\left(\mathrm{H}_{2} \mathrm{O}\right)_{6} \mathrm{~V}_{10} \mathrm{O}_{28}$. $18 \mathrm{H}_{2} \mathrm{O}$, Biomed. Pharmacother., 2009, 63, 51-55.

26 R. Raza, A. Matin, S. Sarwar, M. Barsukova-Stuckart, M. Ibrahim, U. Kortz and J. Iqbal, Polyoxometalates as potent and selective inhibitors of alkaline phosphatases with profound anticancer and amoebicidal activities, Dalton Trans., 2012, 41, 14329-14336.

27 L. De Matteis, S. G. Mitchell and J. M. de la Fuente, Supramolecular antimicrobial capsules assembled from polyoxometalates and chitosan, J. Mater. Chem. B, 2014, 2, 7114-7117.

28 A. Bijelic, M. Aureliano and A. Rompel, The antibacterial activity of polyoxometalates: structures, antibiotic effects and future perspectives, Chem. Commun., DOI: 10.1039/c7cc07549a.

29 A. Blazevic and A. Rompel, The Anderson-Evans polyoxometalate: From inorganic building blocks via hybrid organic-inorganic structures to tomorrows "Bio-POM", Coord. Chem. Rev., 2016, 307, 42-64.

30 L. de Meis and A. L. Vianna, Energy interconversion by the $\mathrm{Ca}^{2+}$-dependent ATPase of the sarcoplasmic reticulum, Annu. Rev. Biochem., 1979, 48, 275-292.

31 C. Toyoshima, M. Nakasako, H. Nomura and H. Ogawa, The structural basis for coupling of $\mathrm{Ca}^{2+}$ transport to ATP hydrolysis by the sarcoplasmic reticulum $\mathrm{Ca}^{2+}$-ATPase, Nature, 2004, 405, 647-655.

32 L. Yatime, M. J. Buch-Pedersen, M. Musgaard, J. P. Morth, A.-M. L. Winther, B. P. Pedersen, C. Olesen, J. P. Andersen, 
B. Vilsen, B. Schiøtt, M. G. Palmgre, J. V. Møller, P. Nissen and N. Fedosova, P-type ATPases as drug targets: tools for medicine and science, Biochim. Biophys. Acta, 2009, 1787, 207-220.

33 G. Fraqueza, C. A. Ohlin, W. H. Casey and M. Aureliano, Sarcoplasmic reticulum calcium ATPase interactions with decaniobate, decavanadate, vanadate, tungstate and molybdate, J. Inorg. Biochem., 2012, 107, 82-89.

34 M. B. Colović, D. V. Bajuk-Bogdanovic, N. S. Avramovic, I. D. Holclajtner-Antunovic, N. S. Bošnjaković-Pavlovic, V. M. Vasić and D. Z. Krstić, Inhibition of rat synaptic membrane $\mathrm{Na}^{+} / \mathrm{K}^{+}$-ATPase and ecto-nucleoside triphosphate diphosphohydrolases by 12-tungstosilicic and 12-tungstophosphoric acid, Bioorg. Med. Chem., 2011, 19, 7063-7069.

35 Inorganic Chemistry, ed. A. P. Ginsberg, Wiley, New-York, 1990, vol. 27, pp. 71-132.

36 K. J. Schmidt, G. J. Schrobilgen and J. F. Sawyer, Hexasodium hexatungstotellurate(vi) 22-hydrate, Acta Crystallogr., 1986, C42, 1115-1118.

37 W. Kraus, H. Stephan, A. Röllich, Z. Matějka and G. Reck, $\mathrm{K}_{6} \mathrm{H}_{2}$ [TiW11CoO40] $13 \mathrm{H}_{2} \mathrm{O}$, with a monotitanoundecatungstocobaltate(II) anion, Acta Crystallogr., 2005, E61, i35-i37.

38 C. Tourné, A. Revel, G. Tourné and M. Vendrell, Heteropolytungstates containing elements of phosphorus family with degree of oxidation(III) or (v)-identification of species having composition $\mathrm{X}_{2} \mathrm{~W}_{19}$ and $\mathrm{XW}_{9}(\mathrm{X}=\mathrm{P}, \mathrm{As}, \mathrm{Sb}, \mathrm{Bi})$ and relation to those with composition $\mathrm{XW}_{11}$, C. R. Seances Acad. Sci., Ser. C, 1973, 277, 643-645.

39 U. Kortz, M. G. Savelieff, B. S. Bassil and M. H. Dickman, A large, novel polyoxotungstate: $\left[\mathrm{As}_{6}^{\mathrm{III}} \mathrm{W}_{65} \mathrm{O}_{217}\left(\mathrm{H}_{2} \mathrm{O}\right)_{7}\right]^{26-}$, Angew. Chem., Int. Ed., 2001, 40, 3384-3386.

40 J. Gao, J. Yan, S. Beeg, D.-L. Long and L. Cronin, One-pot versus sequential reactions in the self-assembly of gigantic nanoscale polyoxotungstates, J. Am. Chem. Soc., 2013, 135, 1796-1805.

41 H. N. Miras, J. Yan, D.-L. Long and L. Cronin, Structural evolution of "S"-shaped $\left[\mathrm{H}_{4} \mathrm{~W}_{22} \mathrm{O}_{74}\right]^{12-}$ and "§"-shaped
$\left[\mathrm{H}_{10} \mathrm{~W}_{34} \mathrm{O}_{116}\right]^{18-}$ isopolyoxotungstate clusters, Angew. Chem., Int. Ed., 2008, 47, 8420-8423.

42 M. Aureliano, F. Henao, T. Tiago, R. O. Duarte, J. J. G. Moura, B. Baruah and D. C. Crans, Sarcoplasmic reticulum calcium ATPase is inhibited by organic vanadium coordination compounds: pyridine-2,6-dicarboxylatodioxovanadium(v), BMOV, and an amavadine analogue, Inorg. Chem., 2008, 47, 5677-5684.

43 K. J. Karnaky Jr, K. J. Degnan and J. A. Zadunaisky, Chloride transport across isolated opercular epithelium of killifish: a membrane rich in chloride cells, Science, 1977, 195, 203-205.

44 J. A. Zadunaisky, The chloride cell: the active transport of chloride and the paracellular pathways, Fish Physiology, XB, ed. W. S. Hoar, D. J. Randall, Academic Press, New York, 1984, 129-176.

45 J. A. Martos-Sitcha, G. Martínez-Rodríguez, J. M. Mancera and J. Fuentes, AVT and IT regulate ion transport across the opercular epithelium of killifish (Fundulus heteroclitus) and gilthead sea bream (Sparus aurata), Comp. Biochem. Physiol., Part A: Mol. Integr. Physiol., 2015, 182, 93-101.

46 G. Fraqueza, L. A. E. Batista de Carvalho, M. Paula, M. Marques, L. Maia, C. André Ohlin, W. H. Casey and M. Aureliano, Decavanadate, decaniobate, tungstate and molybdate interactions with sarcoplasmic reticulum $\mathrm{Ca}^{2+}$-ATPase: quercetin prevents cysteine oxidation by vanadate but does not reverse ATPase inhibition, Dalton Trans., 2012, 41, 12749-12758.

47 S. Hua, G. Inesi and C. Toyoshima, Distinct topologies of mono- and decavanadate binding and photo-oxidative cleavage in the sarcoplasmic reticulum ATPase, J. Biol. Chem., 2000, 275, 30546-30550.

48 M. Aureliano, G. Fraqueza and C. A. Ohlin, Ion pumps as biological targets for decavanadate, Dalton Trans., 2013, 42, 11770-11777.

49 K. J. Degnan, K. J. Karnaky, Jr. and J. A. Zadunaisky, Active chloride transport in the in vitro opercular skin of a teleost (Fundulus heteroclitus), a gill-like epithelium rich in chloride cells, J. Physiol., 1977, 271, 155-191. 